\title{
THE ROLE FINANCIAL SERVICES AUTHORITY OF INDONESIA IN ORDER TO SUPPORT RURAL BANK/ISLAMIC RURAL BANK SUSTAINABILITY
}

\author{
Maria Widyastuti ${ }^{1}$, Stephanie Astrid Ayu ${ }^{2}$ \\ ${ }^{1,2}$ Faculty of Economics, Universitas Katolik Darma Cendika \\ Email: maria.widyastuti@ukdc.ac.id, astrid.ayu@ukdc.ac.id
}

\begin{abstract}
The financial services authority (OJK) released data, in all of Indonesia half of the existing rural bank/Islamic rural banks have not met the minimum capital according to the Financial Services Authority Regulation (POJK) No.5/POJK.03 / 2015, which is IDR 3 billion and IDR 6 billion according to the size of their business so far, until December 31, 2019. Of course, with the data released by the OJK, many rural bank/Islamic rural banks will be forced to stop their operations. This research aims to analyze the role of POJK in supporting the sustainability of rural bank/Islamic rural banks. This research was carried out through the following stages: 1) the researcher conducted in-depth interviews with informants with a questionnaire guide; 2) to support the results of the interview, a literature study was also conducted, especially regarding regulations related to marketing products / services; 3) from the results of the interview tabulations are made to make it easier to read the results of the interviews, 4) discuss the tabulated data so that the condition of the rural bank/Islamic rural banks can be seen, 5) make conclusions. The results of this research found that rural bank/Islamic rural banks with a fund of Rp.500,000,000, - for the time being unable to cover the risk that must be borne by rural bank/Islamic rural banks, it is necessary to have a POJK which regulates the minimum core capital. POJK is also very much needed so that rural bank/Islamic rural banks can run their business more efficiently, effectively, transparently and accountably and be able to compete fairly with other financial institutions.
\end{abstract}

Keywords: $\quad$ POJK, rural bank/Islamic rural banks sustainability

\section{Introduction}

OJK announced the data that there are at least 722 rural bank/Islamic rural banks across Indonesia that are threatened with sanctions in the form of restrictions on their business activities in 2020. Consisting of 374 rural bank/Islamic rural banks with core capital below IDR 3.M and the remaining 348 rural bank/Islamic rural banks having core capital of around IDR 3M - Rp. 6 billion. This indicates that the rural bank/Islamic rural banks have not met the minimum core capital requirements according to POJK. The POJK stipulates that Rural bank/Islamic rural banks are required to meet core capital of IDR 3 billion and IDR 6 billion by the end of 2019 at the latest.

This regulation resulted in one BPR (Panca Marga) and One rural bank/Islamic rural banks (Jabal Tsur) forced to close due to the capital adequacy ratio below provisions rural bank/Islamic rural banks are required to make changes in order to adapt to the POJK and compete with other institutions engaged in finance, which are now starting to lose their market share, this is the impact of the increasing number of institutions standing everywhere. The players are not only companies, but individuals who have unemployed funds, there are even companies that finance the purchase of new vehicles, so the practice of pawning BPKB can be predicted that there will be many leasing companies. This condition is less of a serious concern from both the government and banking institutions, even though such practices can harm banks and also teach the public unfavorable 
International Journal of Economics, Business and Accounting Research (IJEBAR)

Peer Reviewed - International Journal

Vol-4, Issue-3, 2020 (IJEBAR)

E-ISSN: 2614-1280 P-ISSN 2622-4771

http://jurnal.stie-aas.ac.id/index.php/IJEBAR

lessons. In addition, large banks have a trend to establish micro units, to reach their customers who have so far not been able to be assisted through commercial bank loan

With government programs that collaborate with commercial and regional banks, it will threaten the sustainability of rural bank/Islamic rural banks in the community. The rural bank/Islamic rural banks will assist entrepreneurs from their establishment until they grow up and then be introduced to banks that are rural bank/Islamic rural banks colleagues. POJK issued with the hope that the rural bank/Islamic rural banks will make improvements. Regulations related to products / services and marketing of rural bank/Islamic rural banks include: banking law, consumer protection, office-free financial services, business activities by region, zoning by zoning and finally, SEOJK regarding risk management.

Specific objectives to be achieved, so that rural bank/Islamic rural banks operations are sustainable rural bank/Islamic rural banks must make changes towards improvements to show good performance so that they can adjust to the existing POJK (Chou and Buchdadi: 2018). Whereas the urgency, rural bank/Islamic rural banks faces internal company problems, fraud is committed, owners, employees or management, as well as poor bank management, especially in terms of risk management, capital and human resources (Ayuningtyas, 2018). This condition causes the operation to be inefficient, if it is left unchecked, it will cause liquidity problems. The unique location of this research is on how the business that rural bank/Islamic rural banks should do with limited conditions to improve the entire management and management of rural bank/Islamic rural banks, so that they can follow POJK regarding: Consumer Protection, office less financial services, business activities based on core capital, so that they will be maintained continuity.

\section{Method}

The type of this research is qualitative descriptive research which aims to analyze the role of the POJK in order to support the sustainability of rural bank/Islamic rural banks. All social situations that are holistic are the characteristics of qualitative research. Quality actors or resource persons will greatly influence the information needed to uncover the real problems, qualified sources from: OJK who understand POJK and rural bank/Islamic rural banks who understand what steps should be taken for business sustainability

The methods used in data collection are: 1) Contacting informants (OJK; rural banks commissioners and rural banks President Director); 2) Arranging instruments; 3) Extracting field data through interviews, with a list of questions to make it more focused; 4) To refine the results of the interview, a literature study was carried out, especially regarding the Laws and POJKs related to products/services and marketing; 5) Data editing for analysis; 6) Tabulation of data; 7) data analysis; 8) Discussion; 9) Conclusions and Recommendations

Data were analyzed using the model proposed by Miles et al., (2014) which is described in the following figure:

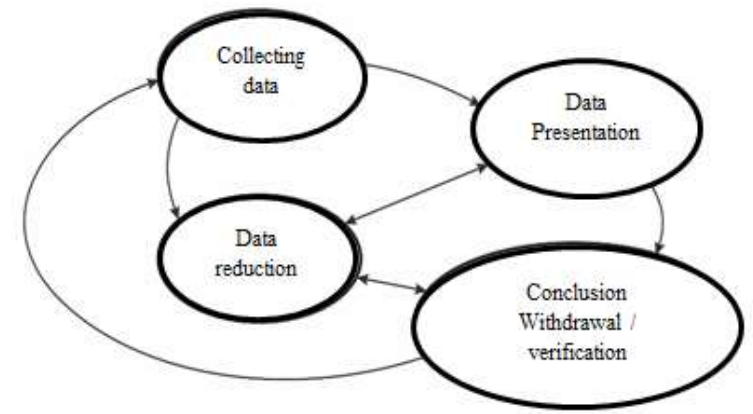

Figure 1

Interactive Model of Qualitative Data Analysis Techniques

Data obtained through informant interviews, with the help of a list of questions as a guide so that the minterview is more focused and on target. Interview techniques are carried out in depth by asking 
International Journal of Economics, Business and Accounting Research (IJEBAR)

Peer Reviewed - International Journal

Vol-4, Issue-3, 2020 (IJEBAR)

E-ISSN: 2614-1280 P-ISSN 2622-4771

http://jurnal.stie-aas.ac.id/index.php/IJEBAR

questions on the problems that are the focus of this research. Literature study techniques were also conducted to determine POJKs related to BPR / S products / services and marketing. Data reduction is meant to sort and simplify the data obtained from in-depth interviews in order to get a real picture with the help of a list of questions, more focused interviews, literature study so that the data collected is more comprehensive. Researchers present data based on the results of interviews conducted carefully and in depth so that data can be presented that reflect the real situation and determine the actions that must be taken. Drawing conclusions is the final stage of all data analysis. In order for consistency, researchers need to double-check between the results of interviews and literature studies with the results of the researchers' notes.

\section{Result and Discussion}

\subsection{Result}

Depositing and channeling funds directly to the public is a characteristic of financial institutions. Storage in the form of short and medium term saving. Meanwhile, the function of making payments is for daily needs, for example: electricity, water and providing credit to people in need. UU. Banking Principal No. 7 of 1992 and Law of the Republic of Indonesia No. 10 of 1998 released banks consisting of: 1) Commercial banks or commercial banks with conventional or Islamic principles. 2) Rural bank/Islamic rural banks activities are conventional or sharia principles and the space for activities is narrower if aligned with commercial banks.

Commercial bank activities are broader than rural bank/Islamic rural banks because commercial banks are more varied in offering products and services, in contrast to BPR / S which is very limited. Commercial bank activities: Collecting funds (current accounts, savings, and deposits), channeling funds (investment, working capital, trading) and providing other bank services (transfers, credit cards, clearing, safe deposit boxes, accepting deposits such as: telephone, serving payments such as: salaries; providing guarantees. While rural bank/Islamic rural banks activities: collecting funds (savings, deposits) and channeling funds (investment, working capital, trading) and not being allowed to carry out activities: accepting deposits of money in the form of demand deposits; handing over securities to each other, trading foreign currency and insurance.

OJK's supervision is a management function apart from planning, organizing and implementing. Supervision needs to be done in all company activities. One of the important areas of supervision is the financial sector, because it is in this area that irregularities often occur. Supervision can also be carried out prior to activities, as a means of preventing irregularities. The purpose of supervision: minimize deviations, in order to work better, activities go according to plan, preventive measures and cost savings. OJK is a milestone for financial industry supervisors so that the economy can compete globally and improve public welfare. OJK is responsible for regulation and supervision. For the community, OJK is very important because it guarantees the security of all activities through financial institution services. For countries OJK plays a role in increasing revenue from the tax sector. For industry, OJK plays a role so that companies are able to carry out their activities smoothly and healthily to get profits for the continuity of their business. OJK has an independent position and is domiciled in the capital city and present in the province if necessary; The OJK Law contains the organization and governance of financial institutions, so that all crimes can be minimized. The presence of the OJK is as important as the presence of the Corruption Eradication Commission (KPK). OJK's principles are: independence, legal certainty, openness, public interest, professionalism, integrity and accountability with the seven principles owned by OJK which are expected to play a role in maintaining good governance of financial institutions.

Law No.10 of 1998, states that financial institutions operate conventionally and do not provide services in payment traffic or under the sharia principles called Rural bank/Islamic rural banks, operate in the MSME sector and are close to the general public. Rural bank/Islamic rural banks businesses include time deposits and other equalization from the community which are then distributed to those in need for the welfare of the community. In the past, BPR / S were known as village banks. Rural bank/Islamic rural banks legal entities can be in the form of: Limited Liability Companies; Cooperatives and Regional Companies. Rural bank/Islamic rural banks are very helpful 
International Journal of Economics, Business and Accounting Research (IJEBAR)

Peer Reviewed - International Journal

Vol-4, Issue-3, 2020 (IJEBAR)

E-ISSN: 2614-1280 P-ISSN 2622-4771

http://jurnal.stie-aas.ac.id/index.php/IJEBAR

for economic growth because in general the customers of Rural bank/Islamic rural banks are Micro, Small and Medium Enterprises or MSMEs (Ackah and Ackah: 2018). The main difference between Rural bank/Islamic rural banks and Commercial Banks is that the activities of Rural bank/Islamic rural banks are more limited compared to commercial banks. BPR / S that has obtained the license have the right to: raise funds, provide credit, and provide financing and placements with Bank Indonesia, time savings, and deposits with other financial institutions. The obligations of Rural bank/Islamic rural banks S include: minimum 25\% share ownership must be owned by at least one person, comply with capital requirements in accordance with the law, submit annual financial reports to OJK, hold a GMS.

Rural bank/Islamic rural banks governance must be healthy in order to compete with commercial banks and be able to follow POJK, of course, Rural bank/Islamic rural banks requires the role of several parties including independent commissioners. Natih's research results (2018) state that good governance at Islamic rural banks will not be effective in areas that are very underdeveloped and highly developed. Tigari and Gaganadeepa's research (2019) explains that BPRs that focus on certain areas and develop entrepreneurship will be able to maintain their existence and operational activities can be sustainable. Devi and Firmansyah (2019) explain how Rural bank/Islamic rural banks gets out of the possibility of bankruptcy, the strategy that must be done is to improve performance and efficiency in every part. That is what can prevent the possibility of bankruptcy. Widyastuti et al (2020) explain that the strategy that Islamic rural banks must implement to face competition and regulation is by branding, improving governance, increasing human resource capacity and conducting mergers. Devi's (2018) research was conducted on Islmaic rural bank in India regarding their problems and prospects, the results of the study show that the problems faced by BPRs in India are governance and human resources but actually have good prospects considering that many home businesses rely on financial assistance from Islamic rural banks. Pratiwi et al (2019), the results of their research, show that most MSME financing comes from Rural bank/Islamic rural banks, when compared to other economic sectors, of course this is more risky. Suheriadi (2017) explained that the Indonesian Deposit Insurance Corporation (LPS) announced that five had been and were undergoing a liquidation process from 2009-2016. The problem that occurs in general is the occurrence of fraudulent practices committed by the owner, employees or management as well as poor bank management, especially in terms of risk management, capital and human resource quality.

\subsection{Discussion}

The requirement of providing a minimum core capital Number 5/POJK.03/2015, aims to build an environment that provides an opportunity for all financial service providers to compete in the good of offering service products more efficiently and competitively. OJK Regional 4 East Java encourages $\mathrm{BPR} / \mathrm{S}$ to join in the framework of banking restructuring. In order to improve the performance of Rural bank/Islamic rural banks, it is necessary to evaluate the action plan undertaken, where each bank is different, some invite investors to choose a merger. Strongly owned capital indicates that the condition of the bank will be better. It is not only Rural bank/Islamic rural banks that need restructuring, but the existence of a commercial bank is also very necessary. The number of banks has decreased due to the merger strategy that has been implemented. In the last three years, the number of Rural bank/Islamic rural banks in East Java has decreased by 18 banks. Bank restructuring efforts in accordance with POJK Number 5/POJK.03/2015 are carried out in stages with a minimum core capital of IDR 3 billion as of 31 December 2019, then, increased to IDR 6 billion in 2024. So that later only Rural bank/Islamic rural banks that are truly healthy will survive. As a result of this regulation in 2019, the Deposit Insurance Corporation (LPS) closed one Islamic rural bank (BPRS Jabal Tsur in Pasuruan Regency) and one rural bank (Panca Dana in Batu City). Alamsyah (2020) writing results of Rural bank/Islamic rural banks which were liquidated due to financial or internal fraud.

The minimum capital requirement linked to the regions will also be imposed by the Rural bank/Islamic rural banks industry. According to POJK No.20/POJK.03/2014, article 5 states, the amount of paid-up capital to establish a Rural bank/Islamic rural banks are: IDR 14,000,000,000 in 
International Journal of Economics, Business and Accounting Research (IJEBAR)

Peer Reviewed - International Journal

Vol-4, Issue-3, 2020 (IJEBAR)

E-ISSN: 2614-1280 P-ISSN 2622-4771

http://jurnal.stie-aas.ac.id/index.php/IJEBAR

zone 1; IDR 8,000,000,000 in zone 2; IDR 6,000,000,000 in zone 3; IDR 4,000,000,000 in zone 4. OJK with certain considerations has the authority to determine the amount of paid-up capital and article 5 explains the division of regions, will look at the economic conditions of a region and the level of competition that occurs between financial institutions within 5 years, called BI as the transition period. Where, this time period is deemed sufficient to make additional capital. Rural bank/Islamic rural banks must improve their competitiveness by increasing capital, infrastructure and improving the quality of human resources. The results showed that the level of profits obtained would be directly proportional to the invested capital (Cyree and Spurlin (2012). This POJK was released with the hope that Rural bank/Islamic rural banks business activities will be healthier in providing services, especially MSMEs and the subsequent impact on national economic growth will increase. One of the competitive elements is capital, but many Rural bank/Islamic rural banks will be forced to close if the minimum capital is too burdensome. BI gives a signal that zoning implementation will not be as strict as commercial banks, but will be more flexible if BPR / S is sufficiently capable of being able to move to the appropriate zoning From the available data, there are sixteen (16) Rural bank/Islamic rural banks in East Java with a minimum capital.

No.12/POJK.03/2016, emphasizes that based on the core capital of BPRs, they are grouped into 3 Business Group Rural Banks (BPRKU), namely: BPRKU 1: less than IDR 15,000,000,000, allowed activities: 1) raising funds in the form of savings (deposits and savings) and loans received; 2) distribution of funds; 3 ) placement of funds (Current accounts, time deposits, savings at commercial banks and Islamic commercial banks), deposits at Rural bank/Islamic rural banks and Bank Indonesia Certificates (SBI); 4) other activities to support the business. BPRKU 2: at least IDR 15,000,000,000 to less than IDR 50,000,000,000. Permitted activities: 1) all activities carried out by BPRKU $1 ; 2$ ) foreign exchange; 3 ) other activities to support the business (debit card issuer, electronic money issuer).

BPRKU 3, at least IDR 50,000,000,000. Activities that are allowed: 1) all activities carried out by BPRKU 2; 2) other activities to support business (Electronic banking service providers and officeless financial service providers in the context of financial inclusion. This regulation provides clear limits on the activities and volume of BPR businesses based on capital owned. This regulation encourages banks to have sufficient capital capacity. to encourage BPRs themselves to face increasingly large and complex business volumes. Without sufficient capital, BPRs will find it increasingly difficult to compete both with fellow BPRs and with other financial institutions. The impact is that BPRs become motivated to have capital that is in accordance with the POJK. Various strategies are carried out in order to maintain BPR sustainability, including: merging and attracting investors. Currently, there are BPRs that are able to meet capital adequacy, although there are still BPRs that have not succeeded in achieving total capital according to OJK regulations.

No 1/POJK.07/2013, this regulation is expected to provide protection to consumers against unhealthy practices carried out by Rural bank/Islamic rural banks. Products and services offered by Rural bank/Islamic rural banks must be easily accessible and obliged to provide correct information. With this regulation, the OJK wants to ensure that consumers of financial services institutions receive protection in the event of a disadvantage. This regulation for financial services institutions also provides legal certainty, procedures and processes if customers feel that they are being disadvantaged. Every Rural bank/Islamic rural banks are required to have a Customer Complaint Service unit (an officer appointed with an SOP in accordance with the procedures determined by the OJK, this regulation has a positive impact on Rural bank/Islamic rural banks, namely it must provide good services to the public and be transparent about the financial products and services provided.

No. 19/POJK.03/2014. Branchiess banking is an innovative development for BPR / S without the need to open a new office. This requires a reliable and digitizing core banking system. The impact on Rural bank/Islamic rural banks, for Rural bank/Islamic rural banks that are already large, they will not experience difficulties in procuring digital technology that has high specifications, but in fact there are still Rural bank/Islamic rural banks that have not been able to reach this technology.

Rural bank/Islamic rural bank is required to implement risk management, No.1/SEOJK.03/2019 Evaluation results for semester 1 of 2019 Regional 4 East Java in global conditions that are still 
International Journal of Economics, Business and Accounting Research (IJEBAR)

Peer Reviewed - International Journal

Vol-4, Issue-3, 2020 (IJEBAR)

E-ISSN: 2614-1280 P-ISSN 2622-4771

http://jurnal.stie-aas.ac.id/index.php/IJEBAR

uncertain, investment conditions are still positive Husdinariyanto (2019) writes a prediction of 5.2 percent economic growth national 2019 will be achieved and inflation will remain at 3.32 percent. The global community released Indonesia was considered positive so that $\mathrm{S} \& \mathrm{P}$ at the end of May 2019 upgraded Indonesia's rating to "BBB" with a stable outlook. East Java's economic growth was 5.51 percent with 2.70 percent, this condition was lower than national inflation (3.32 percent). Apart from that, in East Java, the performance was still considered positive with an increase in banking volume of 8.22 percent, supported by 8.32 percent growth in deposits. Meanwhile, the share of conventional Rural bank/Islamic rural banks assets to the East Java banking industry reached 2.36 percent, while the share of DPK was 1.67 percent and credit was 2.13 percent. Conventional Rural bank/Islamic rural banks has a relatively low market share, but the increase is 5.42 percent, TPF is 6.2 percent and credit is 6.81 percent. This data indicates that Rural bank/Islamic rural banks are still trusted by the people of East Java. The MSME sector is still the backbone of East Java's economic growth, so the role of Rural bank/Islamic rural banks are highly expected. Rural bank/Islamic rural banks NPL in the East Java Region is 8.26 percent, the OJK urges that in increasing the amount of credit, the principle of caution is kept in mind. By utilizing technology and human resources, it is hoped that Rural bank/Islamic rural banks can be adaptive and creative in providing services to the community. A developed Rural bank/Islamic rural banks can be seen from the increasing number of networks and the more complex services and activities offered, the OJK requires implementing risk management.

Risk management is established through SEOJK No.1 / SEOJK.03 / 2019 with the hope that Rural bank/Islamic rural banks can improve their institution, reputation, and competitiveness in a sustainable manner. Due to the development of information technology and the tighter competition, additional capital and increased human resource capabilities are very important needs. East Java Rural bank/Islamic rural banks performance evaluation semester II of 2019 aims to conduct capacity building for Rural bank/Islamic rural banks Directors and Commissioners. For the future, economic fluctuations remain a challenge for Indonesia that must be watched out for. However, the results of the evaluation in the third semester of 2019, the economic growth of East Java is still quite encouraging, namely $5.32 \%$ greater than the national economic development of $5.02 \%$. The development of banking in East Java has experienced a positive development up to the position of October 2019, seen asset development of 7.73\%. Meanwhile, deposits and credit increased to 7.64\% and $4.04 \%$. Specifically for business volume and deposits, growth was higher than the growth of the national banking industry, which amounted to $6.06 \%$ and $6.39 \%$, respectively. Meanwhile, for credit, national banking growth was still higher at $6.63 \%$. compared to the growth of the East Java banking. Rural bank/Islamic rural banks business volume in East Java grew 9.88\%, TPF grew $10.81 \%$ and credit grew $9.50 \%$. Meanwhile, Rural bank/Islamic rural banks in East Java developed in line with the development of business volume, DPK and credit amounting to $11.58 \%, 13.36 \%$ and $11.50 \%$, respectively. BPRs are also reminded to always consider carefully when expanding their business and expect to comply with an NPL ratio of $4.17 \%$ as targeted in 2019. Recent developments have resulted in very tight competition between financial institutions including Rural bank/Islamic rural banks, as well as from a credit program with an interest rate of $6 \%$ starting January 2020. In order to deal with this, East Java Rural bank/Islamic rural banks are expected to find opportunities that lie behind these challenges. In the current era of economic disruption, we all have to be agile and able to make changes in order to survive in the industry. Digital transformation has entered all aspects of people's lives, so that it is able to change lifestyles. The ease and speed of obtaining services have become the demands and needs of today's society, especially for the millennial generation. These are all opportunities that must be seized by Rural bank/Islamic rural banks so that innovation and high creativity in developing banking products and services are critical factors for success. Rural bank/Islamic rural banks faces various obstacles in carrying out digital transformation. High investment and operational costs as well as human resource readiness are the main problems that must be resolved by Rural bank/Islamic rural banks amidst constraints of limited capital and shareholder support (Nashihin and Harahap (2014). To overcome these obstacles, Rural bank/Islamic rural banks 
International Journal of Economics, Business and Accounting Research (IJEBAR)

Peer Reviewed - International Journal

Vol-4, Issue-3, 2020 (IJEBAR)

E-ISSN: 2614-1280 P-ISSN 2622-4771

http://jurnal.stie-aas.ac.id/index.php/IJEBAR

can collaborate with institutions this is important because synergy and collaboration are the main keys to the success of the company.

\section{Conclusion}

Minimum Capital Adequacy Requirement, resulting in LPS being forced to close one BPRS in Pasuruan Regency, Jabal Tsur and one rural bank in Kota Batu, BPR Panca Dana. Based on the amount of paid-up capital to establish a Rural bank/Islamic rural banks, it is divided into 4 zones, where the division is based on the competition that occurs between financial institutions and the economic potential of a region. OJK emphasized that the core capital owned by rural bank is a requirement for business activities and office network area. BPRs are grouped into 3 Business Group Rural Banks (BPRKU), namely: BPRKU 1, BPRKU 2, BPRKU 3. The settlement process if the customer feels disadvantaged. The regulation regarding branchiess banking is an innovation in the development of Rural bank/Islamic rural banks without the need to open a new SEOJK office regarding the implementation of risk management for Rural bank/Islamic rural banks. The performance of Rural bank/Islamic rural banks East Java is still well maintained in terms of the level of public trust. Rural bank/Islamic rural banks cannot bear the risk if the minimum capital is IDR 500 million. Rural bank/Islamic rural banks that have not been able to meet the minimum capital are recommended to move to the zone according to their capabilities. POJK aims to build an environment that provides opportunities for all financial institutions and non-financial institutions to compete in the goodness of offering service products more efficiently and competitively.

The increase in fintech companies is a tough competition for Rural bank/Islamic rural banks, the ease and speed of obtaining services has become the demands and needs of today's society, especially for the millennial generation. Rural bank/Islamic rural banks face various obstacles in carrying out digital transformation. Investment costs, high operational costs and readiness of human resources are the main problems that must be resolved by Rural bank/Islamic rural banks amid the constraints of limited capital and shareholder support. To overcome these obstacles, collaboration between Rural bank/Islamic rural banks or with other financial institutions can strengthen the position of the Rural bank/Islamic rural banks. This is important because synergy and collaboration are the main keys to the company's success.

\section{Acknowledgment}

On this occasion we would like to thank to Katolik Darama Cendika University for providing financial support. Apart from that we also would like to thank: 1) Mr. FX. Soegeng Notodiharjo as commissioner three BPR, namely: PT BPR Indra Candra in Singaraja, PT BPR Cahaya Fajar in Cirebon and PT BPR Porong Idaman in Porong, 2) Mr. Budiyono Gani Setiawan as the main director of PT. BPR Dana Raya in East Java, 3) Mrs. Ratna Widyanti As the main director of PT BPR Danamitra Surya, in East Java 4) OJK East Java, who has taken the time to provide information and input on the topics discussed in the research. Hopefully their willingness to help us get abundant blessings from God Almighty.

\section{References}

Peraturan Otoritas Jasa Keuangan (POJK) No 5/POJK.03/2015, https://www.ojk.go.id/id/regulasi/Pages/POJK-tentang-Kewajiban-Penyediaan-ModalMinimum-dan-Pemenuhan-Modal-Inti-Minimum-BPR.aspx Mnggu 19 April 2020 jam 13.30

Undang- Undang No 10 Tahun 1998 sebagai Pengganti Undang -Undang No 7 Tahun 1992 https://www.jogloabang.com/pustaka/uu-10-1998-perubahan-uu-7-1992-perbankan Minggu 19 April 2020 jam 13.35

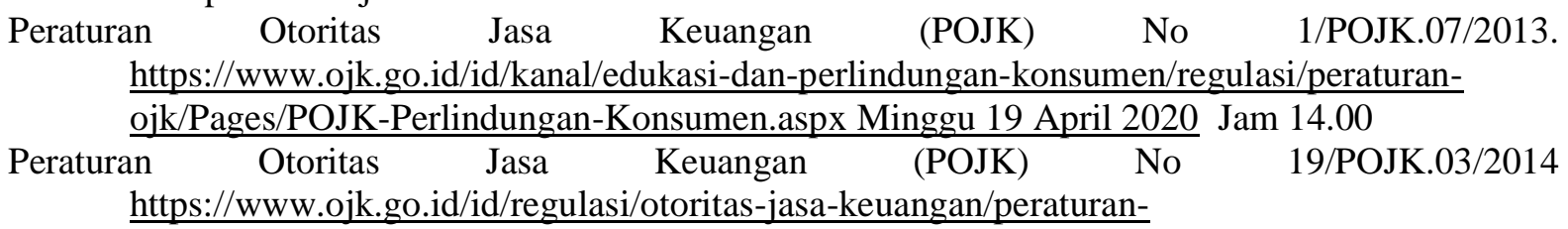


International Journal of Economics, Business and Accounting Research (IJEBAR)

Peer Reviewed - International Journal

Vol-4, Issue-3, 2020 (IJEBAR)

E-ISSN: 2614-1280 P-ISSN 2622-4771

http://jurnal.stie-aas.ac.id/index.php/IJEBAR

ojk/Documents/POJK19LayananKeuanganTanpaKantor 1417076222.pdf Minggu 19 April 2020 Jam 15.00

$\begin{array}{lllll}\text { Peraturan } & \text { Otoritas Jasa Keuangan (POJK) No 12/POJK.03/2016 }\end{array}$ https://m.hukumonline.com/pusatdata/detail/1t56f12e0bcb54a/nprt/lt534b91334ce19/peraturan -otoritas-jasa-keuangan-no-12_pojk.03_2016-tahun-2016-kegiatan-usaha-dan-wilayahjaringan-kantor-bank-perkreditan-rakyat-berdasarkan-modal-inti Minggu 19 April 2020 Jam 15.30

Peraturan Otoritas Jasa Keuangan (POJK) No 20/POJK.03/2014

https://www.ojk.go.id/id/regulasi/otoritas-jasa-keuangan/peraturanojk/Documents/POJK20KelembagaanBankPerkreditanRakyat_1417076232.pdf Senin 20 April 2020 jam 12.00

Surat Edaran Otoritas Jasa Keuangan (SEOJK) No.1/SEOJK.03/2019

https://www.ojk.go.id/id/regulasi/Documents/Pages/Penerapan-Manajemen-Risiko-bagiBank-Perkreditan-Rakyat/SAL\%20SEOJK\%20NOMOR\%201\%20-\%202019.pdf Senin 20 April 2020 jam 13.00

Chou, T,K and A.D. Buchdadi (2018) Bank Performance and Its Underlying Factors: astudy of rural Banks in Indonesia. Accounting and Finance Research Vol 5 no 3 ISSN 1927-5986

Ayuningtyas,R.D., R Wati and F Safa'ah ( 2018) Sustainability of Sharia Rural bank in Central Java. Jurnal Ekonomi \& Keuangan Islam Vol4 No2 DOI 10.20885.JEK vol4.iss2.url

Ackah, D. and E. Ackah (2018) The Impact od Rural Banking on Economic

DevelopIssuement. International Journal of Research Vol1, Issuer 1, pp: 112-120

Peraturan Otoritas Jasa Keuangan (POJK) No 20/POJK.03/2014 https://www.ojk.go.id/id/regulasi/otoritas-jasa-keuangan/peraturan/Documents/POJK20KelembagaanBankPerkreditanRakyat_1417076232.pdf Senin 20 April 2020 jam 12.00

Natih, P.G.L (2018) Technical Efficiency Levels of Rural Banks (BPRs) in West Java: A Stochastic Frontier Approach. Economics and Finance in Indonesia Vol 61 No 3 ISSN 0126155X , pp 223-230

Tigari, H.,and M.G Gaganadeepa (2019) Regional Rural Banks and Rural Development: A Case of Pragathi Krishna Gramin Bank, International Journal of Economic Vol 7, Issue 2, ISSN 2319-961X

Devi,A., and I Firmansyah (2018) Solution to Overcome The Bankruptcy Potential of Islamic rural bank in Indonesia, Journal of Islamic Monetary Economic and Finance Vol 3, Special Issue pp:25-44, ISSN 2460-674

Widyastuti,M., Y.B.Hermanto., Lusy (2020) The Competition and Regulation are Challenges for Rurals Banks, JOURNAL XI'AN UNIVERSITY OF ARCHITECTURE \& TECHNOLOGY Vol XII, Issue II ISSN 1006-7930

Devi, N.S (2016) Problems and Prospects of Regional Rural Bank in India. International Journal of Management Studies and Research, (IJMSR) Vol 2 Issue 3 ISSN 2359-0330.

Pratiwi ,A., B,N,D Puspita dan S Wahyudi (2019) Pengujian Potensi Kebangkrutan Grup Bank Pembiayaan Syariah di Indonesia, Jurnal Economia Vol 15.No 1. ISSN: 1858-2648 , pp 114134

Suheriadi (2017) Ini 5 Masalah yang gerogoti BPR secara Internal Infobanknews Retrieved March 25,2019 from http://infobanknews.com/ini-5-masalah-yang-gerogoti-bpr-secara-internal/ Senin 20 April 2020 jam 14.00

Miles, MB.,A.M Hubermen dan J Saldana (2014) Qualitative Data Analysis, A Method Sourcebook The Third Edition SAGE

Alamsyah I.E (2020) POJK 5/2015, OJK Terus Dorong Merger BPR di Jawa Timur Jumat 17 Jan 2020 23:44 WIB

https://republika.co.id/berita/q49fug349/ojk-terus-dorong-merger-bpr-di-jawa-timur Minggu 28 Juni 2020 jam 12.00 
International Journal of Economics, Business and Accounting Research (IJEBAR)

Peer Reviewed - International Journal

Vol-4, Issue-3, 2020 (IJEBAR)

E-ISSN: 2614-1280 P-ISSN 2622-4771

http://jurnal.stie-aas.ac.id/index.php/IJEBAR

Trinugroho I.,T Risfandy and M.D Ariefianto (2018) Competition, Diversification and Bank Margins: Evidence From Indonesian Islamic Rural Banks, Borsa Istanbul - Review 2214-8450, XX (2018) $1-10$

Cyree, K.B and W.P Spurlin (2012) the Effects of Big -Bank Presence On theProfit Efficiency Of Small Banks in Rural Markets, Jurnal of Banking \& Finance 36, 2593-2603

Nashihin M. and L Harahap (2014) Thr Analysis of theEfficiency of BPR-S. Production Function Approach VS Financial Ratios Approach Procedia - Sosial and Behavioral Sciences 115 (2014) 188-197

Husdinariyanto, N. (2019) OJK evaluasi kinerja BPR se-JawaTimur

Senin, 1 Juli 2019 18:42 WIB, Editor : Didik Kusbiantoro,

https://jatim.antaranews.com/berita/303180/ojk-evaluasi-kinerja-bpr-se-jawa-timur Saptu 27

juni 2020 jam 11.00 